\title{
Commentary
}

\section{The Atacama skeleton}

\author{
Garry Nolan ${ }^{1,3}$ and Atul Butte 2,3 \\ ${ }^{1}$ Baxter Laboratory for Stem Cell Biology, Department of Microbiology and Immunology, Stanford University, Stanford, \\ California 94305, USA; ${ }^{2}$ Institute for Computational Health Sciences, University of California San Francisco, San Francisco, \\ California 94158, USA
}

The recent publication of the genetic analysis of the so-called Atacama skeleton (Bhattacharya et al. 2018) has raised important questions in the biological, archaeological, and anthropological communities. We have clearly stated previously that this skeleton should be repatriated and accorded proper respect as human remains and we echo recent demands for its repatriation.

Further, we feel that our results call for immediate and more urgent attention to the many complex issues related to the study of human remains. A recent editorial in Nature (Callaway 2018) that relates to studies of ancient humans, poignantly speaks to the respect that is called for when studying any human remains, and our recent communications with scientists, especially Chilean researchers, have deepened our insight into the need to incorporate cultural, historical, and political perspectives when studying ancient (or non-ancient) human DNA.

There are varying accounts regarding the original discovery of the skeleton, including some that state the skeleton was originally found in 2003 on a shelf in a building near a church in La Noria. It was then reportedly sold at least twice in Chile, and is now privately held by an individual in Spain. The skeleton has been extensively discussed in outlandish, exploitative, and dehumanizing terms for years in both Chilean and international media, including on the Chilevisión television network, and was used in photography to promote tourism (http://www.estrellaiquique.cl/site/apg/ reportajes/pags/20031019040110.html; stated date: October 19, 2003; accessed March 28, 2018). YouTube has several videos shown in Chile going back at least eight years (one example is https://www.youtube.com/watch?v=xA1wkM_ZHrI; stated date: October 16, 2015; accessed March 28, 2018).

There has been considerable controversy over the years as to the provenance and even the species of the skeleton, most notably including the theories of those who have claimed that the skeleton has an extraterrestrial origin. Despite this previous publicity, to our knowledge, no ethical concerns of the sort recently expressed in a New York Times article (Zimmer 2018) were ever raised in more than a decade of this skeleton being known in Chile, nor since the first scientific studies of the skeleton were discussed in the news media in 2013 (Stone 2013).

Those studies began when a documentary known as Sirius, which featured the skeleton, was being made (Stone 2013), and one of us (G.P.N.) reached out to offer DNA testing. When this research was started, it was not clear that this was a human specimen. It was also not clear how old the skeleton was-the Sirius team claimed it was thousands of years old. It was our intent in this work to bring clarity to the controversies surrounding the skeleton.
It is important to note that no member of the senior authorship team (nor any members of their laboratories) on our recent paper has ever seen or handled the skeleton itself, nor were we involved in its original acquisition, removal, sale, or export. Rather, $\sim 1 \mathrm{~mm}^{3}$ of bone was removed from the skeleton in Spain by the Sirius team, flown to the United States by a member of that team, and provided to Dr. Nolan. To the best of our knowledge, members of the Sirius film team (Greer et al. 2013) handled the skeleton in Spain and took part in any bone removal from the skeleton.

Preliminary analysis of DNA integrity-using the $1 \mathrm{~mm}^{3}$ of bone that was the sole biological sample for all our researchdefinitively proved that the skeleton was 500 years old or less. European DNA admixture and ancestry seen in the DNA that we studied suggests that the skeleton might be considerably younger (Bhattacharya et al. 2018). Separately, radiological films (produced in Spain; no X-rays were obtained at Stanford or UCSF) were provided to our Stanford colleague, Ralph Lachman, an internationally recognized expert in pediatric bone dysplasias, for review.

Both the DNA studies and radiological review were conducted with the utmost respect. Dr. Lachman concluded that the skeleton possessed dysmorphias that were suggestive of a new syndrome or a complex interaction of several disorders. Only through additional analysis was it possible to determine definitively that the DNA we obtained from the skeleton was that of a modern humanand this later analysis and a resulting manuscript were peerreviewed prior to publication in Genome Research. The manuscript underwent three rounds of review before it was accepted, and any concerns on the part of the journal were resolved before acceptance and publication.

By showing beyond a doubt that this is the skeleton of a Chilean human female, the current study and previous work at Stanford in 2013 have at last provided a definitive scientific basis to put a stop to unscientific accounts of the skeleton's true human nature and to accord it the dignity it deserves. As noted, we believe our results underscore the importance of a larger discussion on such samples, including other human remains in anthropological studies currently being discussed in the press.

This was a girl with many DNA mutations, not anything more exotic. Further functional studies of these alterations may lead to a clearer understanding of the genes that regulate bone development and might help the world diagnose and treat other children with genetic diseases driving bone growth abnormalities.

\footnotetext{
${ }^{3}$ These authors have equal senior authorship. Corresponding author: gnolan@stanford.edu

Article published online before print. Article and publication date are at http:// www.genome.org/cgi/doi/10.1101/gr.237834.118. Freely available online through the Genome Research Open Access option.
}

(C) 2018 Nolan and Butte This article, published in Genome Research, is available under a Creative Commons License (Attribution-NonCommercial 4.0 International), as described at http://creativecommons.org/licenses/by-nc/ $4.0 \%$. 


\section{Nolan and Butte}

We hope her remains are treated with respect and have called for those remains to be returned to her native country. We also join in a call for renewed emphasis on educating genomics researchers and other investigators about the sensitive and ethical treatment of human remains.

\section{References}

Bhattacharya S, Li J, Sockell A, Kan MJ, Bava FA, Chen SC, Ávila-Arcos MC, Ji $\mathrm{X}$, Smith E, Asadi NB, et al. 2018. Whole-genome sequencing of
Atacama skeleton shows novel mutations linked with dysplasia. Genome Res 28: 423-431.

Callaway E. 2018. Divided by DNA: the uneasy relationship between archaeology and ancient genomics. Nature 555: 573-576.

Greer S, Virk R, Seraphine JD, Baccam X, Boneshire J, Gerry B. [Producers] and Kaleka A. [Director]. 2013. Sirius [Documentary]. Neverending Light Productions, USA.

Stone R. 2013. "Bizarre 6-inch skeleton shown to be human." Science Now (May 3, 2013). American Association for the Advancement of Science. Retrieved 2013-05-07.

Zimmer C. 2018. "Chile and its scientists protest research on tiny mummy." New York Times, March 29, 2018, p. A8.

\section{Genome Research}




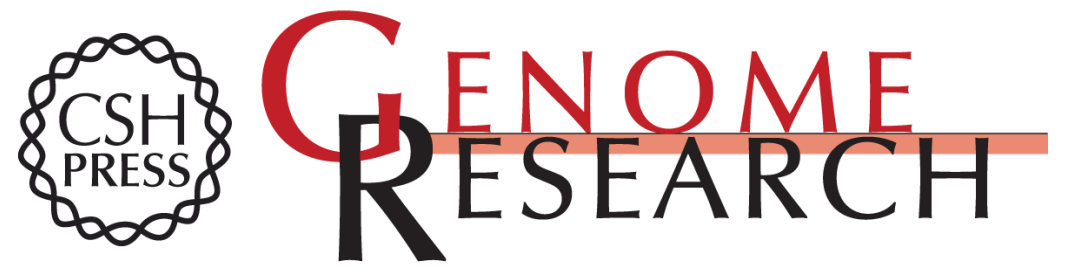

\section{The Atacama skeleton}

Garry Nolan and Atul Butte

Genome Res. 2018 28: 607-608 originally published online March 30, 2018

Access the most recent version at doi:10.1101/gr.237834.118

\section{Related Content Whole-genome sequencing of Atacama skeleton shows novel mutations linked with dysplasia \\ Sanchita Bhattacharya, Jian Li, Alexandra Sockell, et al. Genome Res. April, 2018 28: 423-431 A statement about the publication describing genome sequencing of the Atacama skeleton Genome Res. May, 2018 28: xiv \\ References This article cites 2 articles, 1 of which can be accessed free at: http://genome.cshlp.org/content/28/5/607.full.html\#ref-list-1 \\ Articles cited in: \\ http://genome.cshlp.org/content/28/5/607.full.html\#related-urls \\ Open Access Freely available online through the Genome Research Open Access option. \\ Creative This article, published in Genome Research, is available under a Creative Commons Commons License (Attribution-NonCommercial 4.0 International), as described at License http://creativecommons.org/licenses/by-nc/4.0/.}
Email Alerting Receive free email alerts when new articles cite this article - sign up in the box at the Service top right corner of the article or click here.

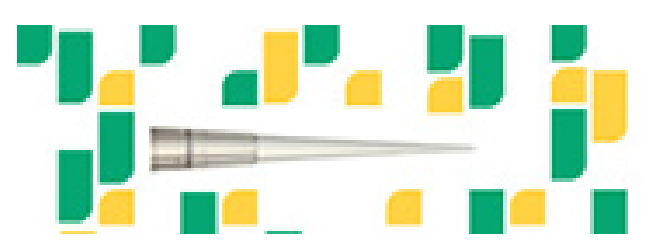

Focused on your science.

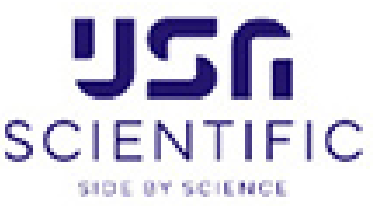

To subscribe to Genome Research go to:

https://genome.cshlp.org/subscriptions 